\title{
Werkgever heeft zorgplicht
}

\section{Het nieuwste OMT-advies over mondmaskers leverde veel reacties op. Los daarvan is het in ieders belang dat de werkgever de werknemer altijd voorziet van beschermende middelen.}

tekst Jeroen Wapenaar

A

ltijd een mondkapje dragen in de thuiszorg is volgens het Outbreak Management Team (OMT) (nog) niet nodig, blijkt uit het op 12 oktober gepubliceerde advies 'Preventief gebruik van mondneusmaskers door zorgmedewerkers in de langdurige zorg'. Overweeg wel om ter bescherming van de cliënt preventief een mondkapje op te zetten, maar beoordeel per cliënt of het echt nodig is, schrijft het OMT. ${ }^{1}$ Beroepsvereniging V\&VN en vakbonden NU'91, FNV, CNV en FBZ adviseren wél altijd preventief een mondneusmasker te dragen en daar alleen van af te wijken als je dat zelf professioneel nodig en verantwoord vindt. De partijen wijzen erop dat volgens het ministerie van VWS er voldoende persoonlijke beschermingsmiddelen op voorraad zijn, ook bij preventief gebruik. ${ }^{2}$

\section{Zorgplicht werkgever}

Het is voor jou en de cliënt verstandig een mondmasker te dragen, benadrukt advocaat Martijn van de Mortel, gespecialiseerd in arbeidsrecht. 'Maar ook voor je werkgever: bij een eventuele juridische procedure wegens een coronabesmetting is hij waarschijnlijk aansprakelijk', zegt Van de Mortel. 'Werkgevers hebben een zorgplicht: ze zijn verplicht de veiligheid en gezondheid van hun werknemers te beschermen', legt hij uit. 'Wettelijk moe- ten ze maatregelen nemen om te voorkomen dat hun werknemers bij de uitoefening van hun werkzaamheden schade lijden. Doet de werkgever dat niet, dan is hij bij schade in beginsel aansprakelijk voor de vergoeding daarvan.'

\section{Bewijslast}

Normaal gesproken is het aan de werknemer om een causaal verband aan te tonen tussen de uitvoering van het werk en de schade. In theorie zou een verpleegkundige die besmet is met het coronavirus zelf moeten bewijzen dat dit komt doordat de zorginstelling onvoldoende maatregelen heeft genomen om besmetting te voorkomen. Bij een juridische procedure rondom een coronabesmetting, legt de rechter echter de bewijslast waarschijnlijk bij de werkgever, verwacht Van de Mortel. 'Dan wordt waarschijnlijk beoordeeld of de zorgverleners mondmaskers droegen en of de werkgever aan zijn zorgplicht heeft voldaan. En als dat niet zo is, moet de werkgever een heel sterk verhaal hebben om onder die aansprakelijkheid uit te komen.'

Je mag dan ook van je werkgever verwachten dat hij er actief op toeziet dat jij en je collega's volgens de instructies handelen, en collega's erop aanspreken als dat niet gebeurt. Ook moeten werkgevers in vergaderingen en op intranet communiceren over wanneer en hoe een

\section{ALTIJD MONDIKAPJE? VERPLEEGKUNDIGEN REAGEREN}

De meeste lezers die reageerden op het OMT-advies willen wel altijd mondkapjes dragen:

Nicole: 'Het OMT-advies zorgt voor veel onrust. Onder zorgpersoneel, maar ook onder cliënten. Waarom meten met twee maten?'

Elke: 'Alle cliënten in de wijk zijn kwetsbaar. Ze hebben niet voor niets wijkverpleging. Gelukkig werken wij al sinds de zomer standaard met chirurgische mondmaskers. Zo is de kans dat wij de cliënten besmetten zo klein mogelijk.'

SEH-verpleegkundige Friso Raemakers vindt dat de afweging beter wel aan de professional overgelaten kan worden: 'Juist een verplichting zorgt in veel situaties voor onrust'.

Rachel: 'Wij dragen al bijna een half jaar mondkapjes. Dat voelt erg veilig voor ons, maar ook voor de cliënten. Het enige nadeel is dat je soms lastig te verstaan bent.'

mondmasker te gebruiken, zegt Van de Mortel.

Noten

1 www.rijksoverheid.nl, zoek op Preventief gebruik van mondneusmaskers door zorgmedewerkers in de langdurige zorg

2 www.venvn.nl, zoek op Gezamenlijk advies V\&VN en vakbonden over gebruik mondneusmasker 